\title{
ÉSZLELT SZÜLÖI NEVELÉS A FIATALOKNÁL: TÁRSAS ÉS TÁRSADALMI HATÁSOK
}

\author{
JÁMBORI SZILVIA ${ }^{1}-$ KÖRÖSSY JUDIT ${ }^{1}$ \\ ${ }^{1}$ Szegedi Tudományegyetem, Pszichológiai Intézet \\ E-mail: szilvia.jambori@psy.u-szeged.hu
}

Benyújtva: 2019. október 07. - Elfogadva: 2020. április 17.

Háttér és célkitûzések: A jelen tanulmány elsô része arra kereste a választ, hogy a szocialista rendszerben nevelkedett fiatal felnôttek és a többnyire új társadalmi, politikai rendszerben szocializálódott serdülók neveléssel kapcsolatos retrospektív észlelése visszatükrözi-e a rendszerváltozással kezdôdô társadalmi és családi átalakulásokat. Részben ezekre az eredményekre támaszkodva a tanulmány második fele azt vizsgálta meg, hogy a két korosztály észlelési különbségét befolyásolja-e a fiatalok aktuális társas kapcsolata, családi helyzete.

Módszer: Az elsố vizsgálatban (2002) 271 fiatal (123 férfi és 148 nö) vett részt, míg a 2. vizsgálatba (2018) 337 fốt vontunk be (149 férfi és 188 nô). Mindkét mérés alkalmával a serdülók és fiatal felnôttek a Családi Szocializáció Kérdôivet (Dalbert és Goch, 1997) töltötték ki, amely a szülói nevelési stílust a fiatalok retrospektív észlelésén keresztül méri.

Eredmények: A két mérési idôpontban a korosztályok részben hasonló dimenziókban észlelték a szülöi nevelést a másodlagos faktorelemzés szerint. A fiatal felnốttek, szemben a serdülókkel, mindkét vizsgálati idöpontban korlátozóbbnak és konformitást hangsúlyozónak észlelték a családi nevelést. A két mérés során azonos konstrukcióval rendelkezố nevelési faktorok összehasonlítása szerint a 2018-as vizsgálatban a serdülók kevesebb konfliktust, a felnôttek pedig gyengébb szabályorientációt, szigorúságot észleltek a szülöi nevelésben, mint a korábbi mérés résztvevối.

Következtetések: A két korosztály hasonlóan észlelt nevelési dimenzióit részben a családi nevelés stabilitásával, a fejlódési fülke homeosztatikus müködésével magyarázhatjuk (Super és Harkness, 1986), részben a család mint értékek változatlanságával. A társadalmi és politikai változás hosszabb távú következményének tekinthetjük azt, hogy a szabadabb légkörben (Robila, 2004) nevelkedō korosztályok kisebb családi konfliktust és kevesebb szabály általi kötöttséget észleltek a családi milióben. A fiatal felnöttek konformitásról és korlátozásról szóló emlékeit leginkább a korosztály sajátos társas és családi helyzetéból adódó észlelési torzitásként értelmezhetjük.

Kulcsszavak: szülôi nevelés percepciója, életkori különbségek, politikai-társadalmi változások, retrospektív vizsgálat 


\section{BEVEZETÉS}

\section{Társadalmi változások és a szülöi nevelés. A család fontossága és a családformák változása. A szülői nevelés a rendszerváltás idôszakában}

Vizsgálatunkban arra kerestük a választ, hogy a rendszerváltozás hatása mennyire érintette a serdülők és fiatal felnôttek szülôi neveléssel kapcsolatos retrospektív észlelését. A rendszerváltó országokban mért vizsgálati eredmények részben azt mutatták, hogy politikai és gazdasági változások nyitottabbá tették a társadalmi csoportokat, köztük a családot is, ugyanakkor a jövedelemszerzés bôvebb lehetôsége gyengítette a család értékét, a nevelésre fordított erôfeszítéseket (Dunovsky, 1996). Így a 2002-es vizsgálatunkban arra kerestük a választ, hogy a rendszerváltás elốtt vagy az után szocializálódott fiatalok neveléssel kapcsolatos észlelésében megjelennek-e az elóbb említett családi jellemzôk, így például a nevelésben észlelhetô konformizmus és engedékenység különbsége. Ezt a vizsgálatot megismételtük 2018-ban, hogy lássuk, mennyire más a fiatalok neveléssel kapcsolatos megítélése jóval a rendszerváltás után, illetve van-e jellemzó életkori különbség a gyerekkorról szóló emlékekben.

A családszociológiai vizsgálatok azt igazolják, hogy a magyar társadalom hagyományosan nagyon értékesnek látja a családi életet, és a család sokkal fontosabb életterületnek számít, mint a munka vagy másfajta társas kapcsolatok (Tóth O., 1997/2006). A 2009-ben végzett vizsgálat szerint az értékek rangsorában a család állt az elsố helyen, és ez az értékválasztás már korábban is jellemezte a magyar társadalmat (Csepeli és Prazsák, 2009). A 2009-ben publikált értékrangsorban a 36 eszköz- és célértéket tekintve például a munka és hivatás a 19., a szabadidó és kikapcsolódás a 18., a barátok a 19. helyre került. A család értékének változatlansága mellett az is igazolható, hogy a családi, a nôi és a férfi szerepekkel kapcsolatos attitûdök minden korosztályban tradicionálisnak mondhatók (Tóth és Dupcsik, 2007; Dupcsik és Tóth, 2008). Ez a tradicionális attitûd, vagyis a családfő vezetô és jövedelemszerzô szerepének, illetve a nôk háztartási és gyermeknevelési feladatának elsôdlegessége jelenti azt az ideológiai familizmust, ami stabillá teszi a családi élet fontosságának értékelését a rendszerváltást megelôzóen és a 2000-es évek közepén is (Dupcsik és Tóth, 2008). A két idôpont között azonban látható bizonyos mértékú változás is (Pongrácz, 2002). Míg a családcentrikusság és a nôi és férfi szerepek hagyományos megosztása volt jellemzô a magyar társadalomra a 70-es évekig, addig a 80-as évekre a részmunkaidôs nôi munkavállalás aránya erôsen megemelkedett. A rendszerváltozás gazdasági hatásai viszont egyrészt erôsítették a nôi munkavállalás szükségességének elfogadását, ugyanakkor erôsítették a családon belüli tradicionális munkamegosztással való egyetértést. A család értékének másik stabilizáló tényezôje a familizmus mint társadalmi állapot, amelyben a rendszerváltás elôtt és után is a civil társadalom erôtlensége és az intézményekben, illetve emberi kapcsolatokban érvényesülő bizalmatlanság formálja a társadalmi tapasztalatokat, és ami éppen ezért a családi kapcsolatokba való visszahúzódásban, a család elsôdlegességének attitûdjében fejezôdik ki (Dupcsik és Tóth, 2008). Az emberi és intézményi kapcsolatokban mutatkozó bizalmatlanság jelenlétét több vizsgálat is igazolja, és ez az attitúd segít fenntartani a familizmust mint társadalmi állapotot (Dupcsik és Tóth, 2008; Tóth I. Gy. 2009; Giczi és Sik, 2009). Bár a családformák változása, a házasodá- 
si és válási magatartás Magyarországon nem tér el jelentősen az európai átlagtól, a vélekedések szintjén mégis a tradicionális családi értékeket látjuk megjelenni. A viselkedés és az attitûd e jól látható következetlenségét Dupcsik és Tóth (2008) azzal magyarázza, hogy a koherens tradicionális értékrend vélhetôen a felnôtteknek csak egy kisebb csoportjára jellemzô, a modernizálódó értéket valló csoportok számára viszont nincs olyan koherens attitûd és az ezt megfogalmazó nyelvezet, amely lehetôvé tenné az új értékek és vélekedések markáns megjelenését, így az ô számukra is csak a tradicionális családfelfogás artikulálható (Tóth és Dupcsik, 2007). A modernizálódó attitűdöket bizonyítja a családi együttélés egyes aspektusával kapcsolatos, 2000 és 2009 közötti mérések összehasonlítása is. Ezek szerint a párkapcsolatok, a családi együttélés formáinak megítélésében bekövetkezô változások a tradicionális normáktól való elmozdulást jelzik (S. Molnár, 2011). A modernizálódás jeleit mutatják az anyák keresó munkájával, a nôi munkavállalással, a partnerek közötti szerepmegosztással kapcsolatos attitúdök is, ami azt mutatja, hogy az egyértelmú gyerek- és családközpontúság elfogadása gyengült, és elfogadottabbá vált az anya jövedelemszerzó szerepe (Pongrácz és S. Molnár, 2011).

A magyarországi és a közép- és kelet-európai országokban folytatott vizsgálatokban, amelyben a rendszerváltás hatásának családi változásait kísérték figyelemmel, egymásnak ellentmondó eredményeket ismerhetünk meg. Dunovsky (1996) elemzése abból indul ki, hogy 1989-ig Közép- és Kelet-Európa országaiban a kommunista ideológia uralkodott, melynek erôteljes befolyása a családi struktúrákra, családon belüli folyamatokra is rányomta bélyegét. Míg a régi rendszerben a családokat nagyon zárt csoportoknak tekintették, addig a szociopolitikai változásokat követôen a családok egyre nyitottabbá váltak, számos más szociális csoporthoz kapcsolódtak, és az egyének ennek következtében a közeli és tágabb szociális szféra számos aspektusában 'kipróbálhatták' magukat. A makroszociális szférában ezek a társadalmi változások viszonylag gyorsan megnyilvánultak, és hatásuk a szociális kapcsolatok szintjén is megfigyelhetô volt. Az emberek számára egyre inkább az lett a legfontosabb, hogy több pénzt keressenek, jobb munkahelyet találjanak, és ennek következtében olyan értékek, mint a család, egyre inkább háttérbe szorultak (Dunovsky, 1996). Más területeken, mint például a kulturális, spirituális és erkölcsi fejlődés ez a változás lassabban jelent meg, azonban a család felelôssége itt is nyomon követhetô (Dunovsky, 1996). Ugyanakkor több közép-európai vizsgálat is azt igazolta, hogy a család a változás után is fontos érték volt, amely stabilitást adott a családtagoknak, és csökkentette a társadalmi hatásokat (Robila, 2004). A gyereknevelés továbbra is az anyák feladata volt, a nevelés gyakorlatában viszont változás történt. Az engedelmesség és a szülôi tekintély mellett megjelent a nevelési stílusban a gyerekek függetlenségének, autonómiájának, szabadságának és önálló döntéshozatalának elfogadása is. A nevelési értékekben a változás után is tovább élt a gyerekek sikeres felnövekedésének, boldogulásának és színvonalas továbbtanulásának biztosítása (Robila, 2004).

A családi nevelést fókuszba emelô pszichológiai vizsgálatok elsôsorban a szülôkre jellemzô nevelési attitűdöket, a nevelési stílust, illetve ezek állandóságát és változását kutatják, és általában nem vagy ritkán térnek ki a család mint érték elemzésére. A hoszszabb távon is változatlanságot mutató nevelési szokások és módszerek értelmezéséhez megfeleló elméleti alapot szolgáltat a fejlődési fülke (developmental niche) elmélet 
(Super és Harkness, 1986). Ez a teória azt hangsúlyozza, hogy a gyerekek fejlôdését a fizikai és társas környezet, a szülók jellemzôii, a gondozási és nevelési szokások három alrendszere mellett meghatározza az a társadalom és kultúra, amelybe beágyazódik (Super és Harkness, 1986). A fejlódés közeli meghatározói biztosítják a rendszer homeosztázisát, így a családi nevelés hosszabb távon, a változó társadalmi és gazdasági környezetben is viszonylagos állandóságot mutat. A kulturális jellemzôk állandóságát az a homeosztatikus múködés biztosítja, amely például egyik fülkeelem változása esetén minimalizálja a kezdeti változást azáltal, hogy az elsố reakció a változásra inkább konzervatív lesz, és így az alrendszer nagyobb része változatlanul meg tud maradni, amihez könnyen kapcsolódhat a másik két változatlan alrendszer. Ha viszont a változás mindegyik alrendszerre átterjed, a homeosztázis miatt egy új összhang alakulhat ki a fülke három eleme között.

A szülői nevelési stílusok hosszú idốn keresztüli fennmaradását a pszichológiai kutatások részben a nevelési minták generációk közötti átadásával is magyarázzák. Jóllehet a generációk közötti nevelési stílus átadása többnyire mérsékelt erôsségú, mégis fontosnak tekinthetô, különösen akkor, ha a közvetítố mechanizmusokat is figyelembe vesszük, például a szülô-gyerek közötti pozitív kapcsolatot vagy az iskolai végzettséget a késốbbi támogató nevelés esetében, vagy a gyerek kíméletlen nevelési tapasztalatát, esetleg antiszociális viselkedését a késôbbi kemény és rossz nevelés hátterében (Belsky, Conger és Capaldi, 2009). Egy japán vizsgálatban például jellegzetes nemi különbségek mutatkoztak: a saját nevelési stílus jellemzése a Szeretet-törôdés és a Túlóvás alskálán az apák esetében hasonló volt, mint a nagyszülóknek tulajdonított nevelési stílus, az anyák csoportjában viszont csak a nagymama és a saját Túlóvás alskála mutatta a generációk közötti hasonlóságot (Kitamura, Shikai, Uji, Hiramura, Tanaka és Shono, 2009). Ez a tanulmány azt is igazolta, hogy a nevelés dimenziói is eltérôen vannak jelen az átadás során: a szeretet kifejezését inkább az ellenkezô nemû́ szülốtôl veszik át a szülôk, míg a gyerek autonómiájával kapcsolatos mintát az anyák a saját nemú szülôtốl sajátítják el. A kötôdési mintázatok generációs átadásának vizsgálata azt bizonyította, hogy a szülốk és a csecsemójük kötôdési besorolása 80\%-ban megegyezik, ami azért is tekinthetố jelentôs eredménynek, mert egyidejú méréssel történt a vizsgálat, és így valódi oksági kapcsolat igazolható (Van IJzendoorn, 1992). A családi nevelési attitúdök pszichológiai vizsgálatai tehát inkább a szülői nevelési stílus és gyakorlat hosszabb távon is mérhetố változatlanságát igazolják. Az egyes családok nevelési stílusában bekövetkezô generáción belüli módosulásokat pedig inkább a családtagok pszichológiai funkcióinak különbözô stressztényezők (pl. súlyos stressz hatása, házastársi konfliktusok, szegénység) hatására bekövetkezô változásával magyarázza (Ponnet, Mortelmans, Wouters, Van Leeuwen, Bastaits és Pasteels, 2013; Guajardo, Snyder és Petersen, 2009).

\section{A szülói nevelés szerepe serdülō- és a fiatal felnôttkorban}

A serdülőkori fejlôdésre sokféle faktor hat: a szülók, a kortársak, az intézmények és újabban az információs technológiai világ alkot olyan dinamikus ökoszisztémás környezetet, amely keretét adja a serdülőkori autonómia és identitás fejlôdésének, illetve 
a kognitív és társas fejlődésnek (Shifflet-Chila, Harold, Fitton és Ahmedani, 2016). Bár a fiatalok kevesebb idôt töltenek a családjukkal és kevesebb interakciót folytatnak a szülőkkel, a szülôi nevelés továbbra is fontos hatással van a rájuk, így a családi nevelés kontextusa sokféle pszichológiai funkciót befolyásol serdülóknél és fiatal felnôtteknél is (Steinberg és Silk, 2002). A szülői nevelés vizsgálatának hagyományos módja a szülố és a gyerek vagy serdülố tapasztalatának megismerése. Bár több vizsgálat is igazolja, hogy a szülôi és a gyermeki észlelés jelentôsen különbözik (Russell, Graham, Neill és Weems, 2016; Dimler, Natsuaki, Hastings, Zahn-Waxler és Klimes-Dougan, 2017), az is igazolható, hogy a szülooktôl származó önbeszámolók hasonlítanak a serdülôk neveléssel kapcsolatos reprezentációihoz (Soenens, Elliot, Goossens, Vansteenkiste, Luyten és Duriez, 2005). A gyerekek és serdülôk jó informátornak tekinthetôk a szülook nevelését illetôen, és több vizsgálat eredményei szerint a fiatalok neveléssel kapcsolatos észlelése összefügg a serdülókori fejlôdés számos területével. Így például igazolható volt, hogy a szüloói elidegenedés és elutasítás észlelése kapcsolatban állt a generalizált szorongással (Hale, Engels és Meeus, 2006). Négy ország serdülőinek vizsgálata azt mutatta, hogy az internalizáló és externalizáló viselkedés pozitívan járt együtt a konfliktusészleléssel, és negatívan a támasz, közelség, kommunikáció és figyelemmel követés észlelésével (Vazsonyi, Hibbert és Snider, 2003). Az aktív megküzdés hátterében az észlelt szülôi melegséget, az autoritatív és permisszív nevelést lehetett igazolni 14-17 éves serdülőknél, a szorongás és a deperszonalizáció viszont az autoriter nevelés tapasztalatához volt köthetô (Wolfradt, Hempel és Miles, 2003). A remény magas pontszáma pozitívan kapcsolódott a demokratikus, elfogadó és túlóvó nevelés észleléséhez, az elutasítás élménye viszont az alacsony reményszintet jósolta be (Kumar, Sharma és Hooda, 2012).

A kezdôdô/formálódó felnôttkor demográfiai szempontból, szubjektív szempontból és az identitásformálódás szempontjából is eltérô életszakasznak tekinthetô a serdülókorhoz és a felnôttkorhoz képest (Arnett, 2000). Arnett és munkatársai (2014) szerint öt jellemzôje van a kezdôdô felnôttkornak, ami a 18-25/30 évig tartó életszakaszt jelenti: a személyes identitás explorációja, az instabilitás, az énfókusz, a kettô között lenni szubjektív érzése, és a lehetôségek és optimizmus érzése. A szülôi nevelés szempontjából a legfontosabb jellemzô az énfókusz, ami azt jelenti, hogy a tekintélyszemélyekkel kapcsolatban kevesebb kötelessége és társas szerepe van a fiatalnak, mint a többi életszakaszban. Ragaszkodhat a szüleihez, jó kapcsolatot is kialakíthat velük, de a szülóknek sokkal kevesebb hatalma és befolyása lesz, mint korábban. A másik fontos jellemzố a kettô között érzése, amelynek során a nem is serdülô, nem is felnôtt állapotból a fiatal eléri a felnôttség egyik kritériumát, a saját magáért vállalt felelôsséget. E két jellemzô lehetôvé teszi, hogy a szülők fokozatosan elfogadják a fiatal felnôtt gyermekeik autonómiáját és erôsödő függetlenségét.

Bár a szüleik a fiatal felnôtteket kevésbé kísérik figyelemmel, és a velük való fizikai közelség is kisebb, mint a serdülốk esetében (Arnett, 2000), sok pszichológiai területen mégis van összefüggés a szülôi bánásmód és a fiatal felnôttek fejlôdési eredményei között. A longitudinális vizsgálat szerint minél erôsebb szülối kontrollt észleltek a kezdô egyetemi hallgatók, annál kevésbé tudtak elkötelezett módon választani, és ezzel a döntéssel azonosulni az identitásformálódás folyamatában. Ugyanakkor a hallgatói széles exploráció, azaz az identitással kapcsolatos keresési, információgyújtési folyamat 
erốs szülôi kontrollt váltott ki, ami - a szülối szándékkal ellentétesen - inkább akadályozta az elkötelezettség kialakítását (Luyckx, Soenens, Vansteenkiste, Groossens és Berzonsky, 2007). A fiatal felnôttkorúak fejlôdési eredményei akkor voltak a leginkább pozitívak, amikor a szülői nevelést melegnek és válaszkésznek, de nem kontrollálónak látták, sốt a szülői involválódás vagy bevonódás hiánya kisebb alkalmazkodási problémával járt együtt, mint az erôs szülói kontroll (Nelson, Padilla-Walker, Christensen, Evans és Carroll, 2011). A fiatal felnőttkorban a szülói helikopter nevelés pozitív hatással van az önértékérzésre, és csökkenti a kockázatos viselkedést, ha a fiatalok úgy észlelik, hogy a szülốk melegséget tanúsítanak velük szemben (Nelson, Padilla-Walker és Nielson, 2015). A helikopter nevelés azt a szülôii magatartást írja le, amikor a szülố ott köröz a gyermek körül, mint egy helikopter, és beavatkozik azokban a helyzetekben, amikor véleménye szerint a gyermek önállóan nem lenne képes kezelni a felmerülô nehézségeket (LeMoyne és Buchanan 2011). A fiatal felnôttkorban is igazolható, hogy nemcsak a szülôi nevelés befolyásolja a fiatalok viselkedését, hanem a fiatalok proszociális viselkedése is hat a szülôi nevelési stílusra: a szülốk nagyobb melegséggel és autonómiabiztosítással válaszoltak a fiatalok családdal kapcsolatos pozitív viselkedésére (Padilla-Walker, Nelson, Fu és McNamara, 2018).

\section{A szülôi nevelés észlelésének torzitásai}

Mivel a gyerekkori szülő́i neveléssel kapcsolatban serdülốket és fiatal felnốtteket kérdeznek meg a kutatók, így felvetôdik a kérdés, hogy mennyire érvényesek azok a megállapítások, amelyeket a fiatalok sok évvel a családi élmények átélése után fogalmaznak meg. A szülôi nevelés visszatekintố észlelése több tényezố miatt is torzult lehet (Gerlsma, Emmelkamp és Arrindell, 1990). A jobb benyomáskeltésért megfogalmazott szándékos torzítás mellett megjelenhet a nem szándékos pontatlanság is, ami a gyenge figyelmi és memóriateljesítménnyel, illetve a múltbeli emlékeknek a jelen fényében történố módosításával magyarázható. Így például a múltbeli negatív tapasztalatokat hajlamos valaki elfelejteni akkor, ha jelenleg nincs problémája. Ezt igazolta Dalton és munkatársainak (Dalton, Frick-Horbury és Kitzmann, 2006) vizsgálata is: azok a fiatalok, akik pozitívnak látták a szülőkkel és a romantikus partnerrel való kapcsolatukat, a gyerekkorra vonatkozó szülői nevelést is pozitívabban jellemezték. További torzító hatásoknak tekinthetốk a szülốkkel szembeni jelenbeli szeretet- vagy ellenségességérzés, illetve a beszámolót adó személyiség jellemzói (Gerlsma és mtsai, 1990). A hangulat befolyásoló hatását a szülői nevelési stílusok megítélésére több vizsgálat is igazolta (Gerlsma és mtsai, 1990; Gillham, Putter és Kash, 2007).

Összességében tehát ezek az eredmények azt mutatják, hogy a serdülốk és fiatal felnốttek észlelése a gyerekkori nevelésrôl nem ad teljesen pontos képet a korai szülói nevelési stílusról. Mivel a szülôi nevelés retrospektív észlelését befolyásolja a hangulat és a társas kapcsolatok minôsége, ez alapján azt mondhatjuk, hogy a gyerekkorra vonatkozó nevelés megítélése bizonyos mértékben tükrözi a fiatalok aktuális mentális állapotát és a társas kapcsolatok minőségét. 


\section{A válás hatása a szülôi nevelésre}

A válást általában megelôzi a házastársak közötti tartós konfliktus, ami megváltoztatja a szüloók nevelési gyakorlatát, és ez negatívan hat a gyerekek viselkedésére. Az apa és az anya közötti konfliktus vagy válás miatt kevésbé hatékonnyá válik a családvezetés és -irányítás (Patterson, 1982). A válás elôtti és utáni konfliktus megváltoztatja az érzelmi légkört a családon belül, és ez direkt hatással van a gyerekek és serdülók iskolai teljesítményére és társas kompetenciájára (Barber és Eccles, 1992). Válás esetén kevésbé autoritatív a szüloói nevelés, kevesebb a szülői támasznyújtás, több a konfliktus a gyerekekkel (Amato, 2000). Lansford (2009) összefoglaló tanulmányában azt említi meg, hogy a szülôk a konfliktus és a válás miatt kevésbé tudják figyelemmel követni és ellenórizni a gyerekeket, kevésbé következetesen fegyelmeznek. A válás olyan stresszt jelent a szülők számára, amely gyengíti a hatékony nevelést, gyakori a szüló és gyerek közötti konfliktus, a nevelést vállaló anyát gyakran jellemzi az irritabilitás, a gyenge kontroll és figyelem, a következetlen és büntetô fegyelmezés (Hetherington és Stanley-Hagan, 2002). A gyerekek gondozását vállaló apák nevelési módszere eltér az anyákéhoz képest, mert bár kevésbé tudják figyelemmel követni a gyerekeket, mégis kevesebb fegyelmezési és kontrollproblémával küzdenek, a gyerekekkel folytatott interakciójukban kevesebb a dicséret, dédelgetés, több a képességgyakorlás és tanítás, és kevésbé figyelnek a gyerekek érzelmi jóllétére és társas kapcsolataira (Hetherington és mtsai, 2002). A gyerekek és serdülook fejlődésére és jóllétére az apa hiánya is hatást gyakorol, és a hatás felnôttkorban is kimutatható (East, Jackson és O’Brien, 2006).

A jelen vizsgálat arra kereste a választ, hogy a politikai változás elôtt szocializálódott fiatalok máshogy látják-e a szülói nevelést, mint azok, akik a rendszerválás után születtek, ezért 2002-ben (1. vizsgálat) megvizsgáltuk a szocialista rendszerben nevelkedett fiatal felnôttek és a többnyire új társadalmi, politikai rendszerben szocializálódott serdülôk neveléssel kapcsolatos retrospektív észlelését. Feltételeztük, hogy a szocialista politikai rendszerben nevelkedett fiatal felnôttek nagyobb mértékben látják konfliktusosnak a családi életet és korlátozóbbnak, konformistának a szülói nevelést, mint a serdülők, akik már a nyitottabb, engedékenyebb, nagyobb autonómiát biztosító szülői és iskolai nevelésben részesültek. Ugyanakkor az is felmerült, hogy a két korosztály észlelési különbségét olyan tényezôk is befolyásolják, mint a fiatalok aktuális társas kapcsolata, családi helyzete. Ezért a vizsgálatot 2018-ban megismételtük. Ebben a 2. vizsgálatban mindkét korcsoport az új társadalmi és politikai rendszer intézményeiben szocializálódott. Tanulmányunkban a két mérési idôpontban vizsgált serdülők és fiatal felnôttek percepciójában mutatkozó eltérésekkel, a négy keresztmetszeti csoport közötti észlelési különbséggel, valamint az elvált és intakt családok fiataljainak eltérô nézeteivel foglalkozunk.

Elsô hipotézisünk az volt, hogy az elsô mérésnél a fiatal felnôttek a serdülookhöz képest kevesebb autonómiát biztosítónak, korlátozóbbnak és célorientáltabbnak tartják a családi nevelést (Robila, 2004), hiszen az ô iskolai és családi szocializációjukban erôsebb volt a szabályozás és a tekintélyelvú irányítás. Második hipotézisünk szerint a fiatal felnốttek a második mérés során nagyobb autonómiát és kevesebb korlátozást észlelnek retrospektív módon a serdülókkel összehasonlítva, hiszen a családjukban a szülôk 
nagyobb mértékben biztosítják számukra a függetlenséget és az önállóságot az új társadalmi értékekkel szinkronban (Robila, 2004), illetve a formálódó felnôtti státusznak megfelelően (Arnett, 2000, Arnett és munkatársai, 2014), és ez az aktuális, vélhetôen pozitív élmény vagy a szülôkkel kialakított kapcsolat befolyásolja a múlt eseményeinek megítélését (Gerlsma és mtsai, 1990). A harmadik hipotézisként azt fogalmaztuk meg, hogy a két mérési idôpontban mindkét korcsoportban hasonló struktúráját láthatjuk a nevelési reprezentációnak, vagyis a serdülook és a fiatal felnôttek hosszabb idôi különbség esetén is hasonló dimenziókban konstruálják meg a szülői neveléssel kapcsolatos tapasztalataikat, tekintettel arra, hogy a nevelési stílusok és ezek észlelése hosszabb távon is hasonló marad (Super és Harkness, 1986), és e változatlansághoz jó alapot biztosít a magyarországi familizmus (Dupcsik és Tóth, 2008). Végül negyedik hipotézisként a családi struktúra hatására vonatkozóan azt feltételeztük, hogy azok a fiatalok, akik egyszülōs családban nevelkedtek, konfliktusosabbnak észlelik az otthoni légkört, szemben a teljes családban felnôtt fiatalokkal, akik sokkal szabályorientáltabbnak és következetesebbnek észlelik szüleik nevelési stílusát (Amato, 2000; Lansford, 2009).

\section{MÓDSZER}

\section{Minta}

1. vizsgálat (2002): Összesen 271 fiatal (123 férfi és 148 nô) vett részt az elsô vizsgálatban 2002-ben. Ebbôl 126 középiskolás (átlagéletkor $=16,6$ év; szórás $=0,57$ ) és 145 (átlagéletkor $=21,5$ év; szórás $=1,9$ ) egyetemista volt. 31 serdülố egyszülős családban nevelkedett, 96 serdüló pedig teljes családban. A fiatal felnôttek csoportjából pedig 119-en teljes családban nevelkedtek, míg 19 fönek elváltak a szülei.

2. vizsgálat (2018): A második vizsgálatban 2018-ban összesen 337 fó vett részt (149 férfi és 188 nô). Két életkori csoportot képeztünk, 14-19 évesek ( $\mathrm{N}=133$, átlagéletkor $=16,8$ év, szórás $=1,36)$ és 20-26 évesek $(\mathrm{N}=204$, átlagéletkor $=21,8$ év, szórás = 1,7). 89 serdülố teljes családban nevelkedett, 22 serdülô pedig elvált szülôk gyermeke. A fiatal felnôtt csoportban pedig 138 fiatal teljes családban, míg 43 fiatal elvált családban élt.

Mindkét vizsgálatban elsôsorban középosztálybeli családból származó fiatalok vettek részt. A fiatalok megítélése alapján a szülook többségében középfokú és felsôfokú végzettségúek voltak (lásd 1. táblázat).

\section{Eszközök}

Mindkét mérési idôpontban a szülôi nevelési stílusok és attitûdök mérése a Családi Szocializáció Kérdôiv (Dalbert és Goch, 1997, magyarul Jámbori, 2007) segítségével történt. A kérdôív a nevelési elvek, attitûdök és nevelési stílusok szerint írja le a családi légkört. A kérdôív elején arra kértük a vizsgálati személyeket, hogy gondoljanak vissza gyermekkorukra, és ennek megfelelően töltsék ki a kérdőívet. A családi légkör dimenzióján belül apára és anyára is minden skála esetén azonos számú állítások szerepeltek. Az állításokat egy 6-fokú, Likert típusú skálán kellett értékelni, melynek végpontjai 1 (egyáltalán nem jellemzô) és 6 (teljes mértékben jellemzó). A kérdőív segítségével a következô dimenziókat tudtuk vizsgálni: Szabályorientált családi légkör (pl. „A mi csa- 
1. táblázat. Szülők iskolai végzettségének megoszlása a mintában (gyakoriságok \%)

\begin{tabular}{l|c|c|c|c}
\hline \multirow{2}{*}{} & \multicolumn{2}{|c|}{ Apa iskolai végzettsége } & \multicolumn{2}{c}{ Anya iskolai végzettsége } \\
\cline { 2 - 5 } & $\mathbf{2 0 0 2}$ & $\mathbf{2 0 1 8}$ & $\mathbf{2 0 0 2}$ & $\mathbf{2 0 1 8}$ \\
\hline Alapfokú & 9 & 7 & 7 & 6 \\
\hline Középfokú (érettségi) & 51 & 45 & 57 & 49 \\
\hline Felsőfokú (diploma) & 40 & 48 & 36 & 45 \\
\hline
\end{tabular}

ládunkban a szabályokat meglehetôsen szigorúan be kell tartani.); Konfliktusos családi légkör (pl. „Családunkban sok veszekedés volt.”); Önállóságra nevelés mint nevelési cél (pl. „Édesanyám/édesapám azt akarta, hogy ruhavásárlásnál saját holmimat magam keressem ki.); Konformitásra nevelés mint nevelési cél (pl. „Édesapám/édesanyám azt akarta, hogy egyek meg mindent, ami az asztalra kerül.”); Következetes beállítottság (pl. „На édesapám/édesanyám megtiltott nekem valamit, tehettem, amit akartam, kitartott álláspontja mellett.”); Manipulatív beállítottság (pl. „Édesanyám/édesapám idônként mondta, hogy több tekintettel lehetnék rá.”); Inkonzisztens nevelés (pl. „Édesapám/ édesanyám összeszidott anélkül, hogy pontosan tudtam volna, miért.”); Támogató attitüd (pl. „Édesanyám/édesapám ugyanúgy meghallgatta a véleményemet, mint egy felnôttét.”); Szemrehányó, korlátozó nevelés (pl. „Édesapám/édesanyám megharagudott volna, ha visszabeszélek neki.").

A demográfiai adatokra a kérdôív végén kérdeztünk rá.

A vizsgálatokban alkalmazott kérdôív reliabilitásmutatóit és leíró statisztikai adatait a 2. táblázat mutatja.

\section{Etikai vonatkozások}

A középiskolások esetében az adatok felvételére (2. vizsgálat - 2018) igazgatói és szülôi engedélyt egyaránt kaptunk, a diákok tanítási órán töltötték ki a kérdôívet, munkájukat a pedagógusok felügyelték. Az egyetemisták önként vehettek részt a kutatásban, és egyetlen elôadás keretében töltötték ki a kérdőívet. A vizsgálat egy nagyobb, komplexebb kutatás keretében zajlott (Dinamikus tudásintegráció - társadalmi megújulás). A vizsgálatot a Pszichológiai Kutatások Egyesült Etikai Bíráló Bizottsága (EPKEB) hagyta jóvá (etikai engedély száma: 2017/125).

\section{EREDMÉNYEK}

\section{Másodrendü faktorelemzés - Az észlelt nevelési stílusok struktúrája a két mintában}

A hipotézistesztelési eljárás elôtt fontos kérdésnek tartottuk annak áttekintését, hogy a négy almintánkban mutatkozik-e különbség a nevelési stílusok faktorszerkezetében. A nevelési stílusok észlelésének összehasonlítása információt szolgáltathat arról, hogy a csoportok faktorstruktúrája mennyire hasonló, és így a mért különbségek tényleges különbségeket tükröznek-e a megítélésében, vagy inkább eltéró észlelési konstrukcióról van szó, ahol másfajta jelentést kaphatnak az egyes dimenziók (Russell és mtsai, 2016). 
2. táblázat. A mérôeszköz reliabilitásmutatói (1-2. vizsgálat, 2002/2018)

\begin{tabular}{|c|c|c|c|c|c|c|}
\hline \multicolumn{2}{|c|}{ Méróeszköz/alskálák } & Állítások & $\begin{array}{c}\text { Átlag } \\
\text { (szórás) } \\
2002 \\
\end{array}$ & $\begin{array}{c}\text { Átlag } \\
\text { (szórás) } \\
2018 \\
\end{array}$ & $\begin{array}{c}\text { Gronbach- } \alpha \\
2002\end{array}$ & $\begin{array}{c}\text { Cronbach- } \alpha \\
2018\end{array}$ \\
\hline \multicolumn{2}{|c|}{$\begin{array}{l}\text { Családi Szocializáció } \\
\text { Kérdôív }\end{array}$} & 47 & & NÉ & & NÉ \\
\hline \multicolumn{2}{|c|}{$\begin{array}{l}\text { Szabályorientált családi } \\
\text { légkör }\end{array}$} & 4 & $3,14(1,02)$ & $3,19(1,03)$ & 0,78 & 0,88 \\
\hline \multicolumn{2}{|c|}{$\begin{array}{l}\text { Konfliktusos családi } \\
\text { légkör }\end{array}$} & 5 & $3,24(0,98)$ & $3,12(0,75)$ & 0,80 & 0,81 \\
\hline \multirow{2}{*}{$\begin{array}{l}\text { Konformitásra } \\
\text { nevelés }\end{array}$} & Apa & 4 & $3,11(0,92)$ & $3,12(1,23)$ & 0,79 & 0,80 \\
\hline & Anya & 4 & $3,22(0,98)$ & $3,28(1,04)$ & 0,71 & 0,70 \\
\hline \multirow{2}{*}{$\begin{array}{l}\text { Önállóságra } \\
\text { nevelés }\end{array}$} & Apa & 3 & $3,11(0,98)$ & $3,97(1,30)$ & 0,72 & 0,71 \\
\hline & Anya & 3 & $3,24(0,89)$ & $3,69(1,07)$ & 0,73 & 0,67 \\
\hline \multirow{2}{*}{$\begin{array}{l}\text { Következetes } \\
\text { nevelési } \\
\text { beállítottság }\end{array}$} & Apa & 2 & $3,44(1,02)$ & $3,48(1,40)$ & 0,67 & 0,69 \\
\hline & Anya & 2 & $3,42(0,88)$ & $3,42(1,19)$ & 0,64 & 0,60 \\
\hline \multirow{2}{*}{$\begin{array}{l}\text { Inkonzisztens } \\
\text { nevelési attitûd }\end{array}$} & Apa & 2 & $2,04(1,29)$ & $2,24(1,48)$ & 0,79 & 0,85 \\
\hline & Anya & 2 & $2,10(1,27)$ & $2,34(1,38)$ & 0,74 & 0,71 \\
\hline \multirow{2}{*}{$\begin{array}{l}\text { Manipulatív } \\
\text { nevelési attitûd }\end{array}$} & Apa & 3 & $2,27(0,97)$ & $2,27(1,00)$ & 0,79 & 0,75 \\
\hline & Anya & 3 & $2,53(1,10)$ & $2,50(1,27)$ & 0,81 & 0,78 \\
\hline \multirow{2}{*}{$\begin{array}{l}\text { Támogató } \\
\text { nevelési attitúd }\end{array}$} & Apa & 3 & $4,24(0.98)$ & $4,21(1,37)$ & 0,80 & 0,82 \\
\hline & Anya & 3 & $4,14(0,87)$ & $4,71(1,15)$ & 0,73 & 0,78 \\
\hline \multirow{2}{*}{$\begin{array}{l}\text { Korlátozó } \\
\text { nevelési attitûd }\end{array}$} & Apa & 2 & $4,23(1,16)$ & $4,11(1,28)$ & 0,71 & 0,83 \\
\hline & Anya & 2 & $4,31(1,37)$ & $4,22(1,47)$ & 0,69 & 0,77 \\
\hline
\end{tabular}

NÉ: nem értelmezhetô

A Kaiser-Meyer-Olkin-mutató mindkét korcsoportban és mindkét idôpontban a vizsgált kérdőív esetében meghaladta a 0,75-ös értéket, vagyis általában a megfelelő kategóriába esett, vagy alig maradt el attól, a válaszok tehát alkalmasak a faktorszerkezet megvizsgálására (Kaiser, 1974 idézi Ketskeméty és Izsó, 1996).

Az elsố vizsgálatban (2002) mind a serdülôk, mint a fiatal felnôttek esetében megvizsgáltuk, hogyan csoportosulnak a nevelési stílusok. A teljes családban nevelkedô serdülók esetében egy háromfaktoros megoldás bizonyult a legjobbnak, 63\%-kal magyarázva a varianciát. Az elsố faktor egy szabályorientált családi légkört írt le, 23\%-kal magyarázva a varianciát, ahol az apai és anyai konformitásra nevelés és korlátozó attitûd volt jellemzô. A második faktor 22\%-kal magyarázva a varianciát egy olyan családi légkört írt le, ahol az apai és anyai következetes beállítottság és az apai támogatás hiánya hangsúlyozódik, emellett a szülôi autonómiatámogatás hiánya figyelhetô meg. A harmadik faktor pedig, 17\%-kal magyarázva a varianciát, egy konfliktusos családi légkört ír le, ahol az apai és anyai manipulatív beállítottság és a támogatás hiánya jelent meg (lásd 3. táblázat).

A fiatal felnôttek esetében egy négyfaktoros megoldás bizonyult a legjobbnak, $66 \%$-kal magyarázva a varianciát. Az elsố faktor, 18\%-kal magyarázva a varianciát, egy szabályorientált családi légkört ír le, ahol az anyai és apai konformitás és a korlátozó attitúd 
volt a meghatározó. A második faktor, 16\%-kal magyarázva a varianciát, egy autonómiát támogató légkört mutat be, ahol mindkét szülố támogató attitûdje hangsúlyozódott (lásd 3. táblázat). A harmadik dimenzió, 16\%-kal magyarázva a varianciát, egy konfliktusos családi légkört szemléltet, ahol a szülői inkonzisztens és manipulatív beállítottság figyelhetô meg. A negyedik faktor, további 15\%-kal magyarázva a varianciát, az apai nevelést emeli ki, ahol a konformitás, következetesség mellett a korlátozó és manipulatív attitûd is megjelent (lásd 3. táblázat). A két korosztály elsố három faktora igen hasonló konstrukciót mutat. A szabályok, korlátozás és konformitás alkotja az elsố faktort, ami jól elkülönül a második faktortól, ahol a következetesség, önállóság és támasznyújtás szempontjai alkottak egy csoportot. A harmadik faktor a konfliktusos és más szempontból is problémás nevelés (manipulatív, következetlen, nem támogató) jellemzôit foglalja magába. Egyedül a fiatal felnôtteknél jelent meg a negyedik faktor, amely az apai viselkedéses jellemzóket tartalmazta (3. táblázat).

3. táblázat. Másodrendú faktorelemzés eredményei (1. vizsgálat, 2002) (faktorsúlyok > 0.30)

\begin{tabular}{|c|c|c|c|c|c|c|c|c|}
\hline \multirow[t]{2}{*}{ Nevelés dimenziói } & \multicolumn{2}{|c|}{ 1. faktor } & \multicolumn{2}{|c|}{ 2. faktor } & \multicolumn{2}{|c|}{ 3. faktor } & \multicolumn{2}{|c|}{ 4. faktor } \\
\hline & serdülô & felnôtt & \begin{tabular}{|l|} 
serdülô \\
\end{tabular} & felnôtt & serdülő & felnôtt & serdülő & felnôtt \\
\hline $\begin{array}{l}\text { Szabályorientált } \\
\text { légkör }\end{array}$ & 0,53 & 0,60 & & & & & & \\
\hline $\begin{array}{l}\text { Korlátozó nevelési } \\
\text { attitûd - Anya }\end{array}$ & 0,78 & 0,69 & & & & & & \\
\hline $\begin{array}{l}\text { Korlátozó nevelési } \\
\text { attitûd - Apa }\end{array}$ & 0,73 & 0,45 & & & & & & 0,80 \\
\hline $\begin{array}{l}\text { Konformitás } \\
\text { nevelési cél - Anya }\end{array}$ & 0,80 & 0,66 & & & & & & 0,42 \\
\hline $\begin{array}{l}\text { Konformitás } \\
\text { nevelési cél - Apa }\end{array}$ & 0,87 & 0,42 & & & & & & 0,71 \\
\hline $\begin{array}{l}\text { Következetes neve- } \\
\text { lési attitúd - Anya }\end{array}$ & & 0,76 & 0,76 & & & & & \\
\hline $\begin{array}{l}\text { Következetes neve- } \\
\text { lési attitúd - Apa }\end{array}$ & 0,58 & & 0,69 & & & & & 0,79 \\
\hline $\begin{array}{l}\text { Önállóságra nevelés } \\
\text { célja - Anya }\end{array}$ & $-0,35$ & & $-0,65$ & 0,79 & & & & \\
\hline $\begin{array}{l}\text { Önállóságra nevelés } \\
\text { célja - Apa }\end{array}$ & & & $-0,91$ & 0,88 & & & & \\
\hline $\begin{array}{l}\text { Támogató nevelési } \\
\text { attitûd - Anya }\end{array}$ & & $-0,33$ & & 0,56 & $-0,68$ & $-0,46$ & & \\
\hline $\begin{array}{l}\text { Támogató nevelési } \\
\text { attitúd - Apa }\end{array}$ & & & $-0,59$ & 0,65 & $-0,57$ & $-0,37$ & & \\
\hline $\begin{array}{l}\text { Inkonzisztens neve- } \\
\text { lési attitûd - Anya }\end{array}$ & & 0,40 & & & 0,74 & 0,66 & & \\
\hline $\begin{array}{l}\text { Inkonzisztens neve- } \\
\text { lési attitûd - Apa }\end{array}$ & 0,36 & & 0,65 & $-0,32$ & 0,31 & 0,50 & & 0,54 \\
\hline $\begin{array}{l}\text { Manipulatív nevelé- } \\
\text { si attitúd - Anya }\end{array}$ & & & & & 0,65 & 0,83 & & \\
\hline $\begin{array}{l}\text { Manipulatív nevelé- } \\
\text { si attitúd - Apa }\end{array}$ & 0,51 & & & & 0,65 & 0,75 & & 0,37 \\
\hline Konfliktusos légkör & & & 0,30 & & 0,68 & 0,71 & & \\
\hline
\end{tabular}


A második vizsgálatban (2018) szintén megvizsgáltuk, hogy mutatkozik-e hasonlóság a két korosztály szülôi nevelésrôl kialakított észlelésének szervezôdésében (lásd 4. táblázat).

A serdülók esetében egy négyfaktoros megoldás bizonyult a legjobbnak, $62 \%$-kal magyarázva a varianciát. Az elsố faktor, 21\%-kal magyarázva a varianciát, egy konfliktusos, nem támogató családi légkört ír le, ahol a szülôk manipulatív beállítottsága és az anyai inkonzisztens és nem támogató nevelési attitúdje hangsúlyozódott. A második faktor, 16\%-kal magyarázva a varianciát, csak az apai következetesség szempontját tartalmazza a támogató attitúddel együtt. Érdekes volt megfigyelni, hogy ebben a családi légkörben az apai inkonzisztens és következetes beállítottság együttesen jelent meg. A harmadik faktor további 14\%-kal magyarázza a varianciát, egy szabályorientált családi légkört ír le, ahol az anyai korlátozó és következetes beállítottság, valamint az apának is tulajdoní-

4. táblázat. Másodrendú faktorelemzés eredményei (2. vizsgálat, 2018) (faktorsúlyok >0,30)

\begin{tabular}{|c|c|c|c|c|c|c|c|c|}
\hline \multirow[t]{2}{*}{ Nevelés dimenziói } & \multicolumn{2}{|c|}{ 1. faktor } & \multicolumn{2}{|c|}{ 2. faktor } & \multicolumn{2}{|c|}{ 3. faktor } & \multicolumn{2}{|c|}{ 4. faktor } \\
\hline & serdülő & felnôtt & serdülő & felnôtt & serdüló & felnôtt & serdülő & felnốtt \\
\hline $\begin{array}{l}\text { Manipulatív nevelé- } \\
\text { si attitûd - Anya }\end{array}$ & 0,86 & & & 0,85 & & & & \\
\hline $\begin{array}{l}\text { Inkonzisztens neve- } \\
\text { lési attitûd - Anya }\end{array}$ & 0,80 & & & 0,82 & & & & \\
\hline Konfliktusos légkör & 0,73 & & & 0,66 & & & & \\
\hline $\begin{array}{l}\text { Támogató nevelési } \\
\text { attitúd - Anya }\end{array}$ & $-0,65$ & & & $-0,54$ & & & & \\
\hline $\begin{array}{l}\text { Manipulatív nevelé- } \\
\text { si attitűd - Apa }\end{array}$ & 0,64 & & & & & 0,52 & & \\
\hline $\begin{array}{l}\text { Korlátozó nevelési } \\
\text { attitûd - Apa }\end{array}$ & & 0,56 & & & & & & \\
\hline $\begin{array}{l}\text { Következetes neve- } \\
\text { lési attitűd - Apa }\end{array}$ & & 0,62 & 0,77 & & & & & \\
\hline $\begin{array}{l}\text { Inkonzisztens neve- } \\
\text { lési attitûd - Apa }\end{array}$ & & & 0,75 & & & 0,88 & & \\
\hline $\begin{array}{l}\text { Támogató nevelési } \\
\text { attitûd - Apa }\end{array}$ & & & 0,72 & & & $-0,66$ & & \\
\hline $\begin{array}{l}\text { Konformitás } \\
\text { nevelési cél - Anya }\end{array}$ & & 0,66 & & & 0,82 & & & \\
\hline $\begin{array}{l}\text { Következetes neve- } \\
\text { lési attitúd - Anya }\end{array}$ & & 0,72 & & & 0,72 & & & \\
\hline $\begin{array}{l}\text { Konformitás } \\
\text { nevelési cél - Apa }\end{array}$ & & 0,71 & & & 0,59 & & & \\
\hline $\begin{array}{l}\text { Szabályorientált } \\
\text { légkör }\end{array}$ & & 0,70 & & & 0,49 & & & \\
\hline $\begin{array}{l}\text { Korlátozó nevelési } \\
\text { attitúd - Anya }\end{array}$ & & & & 0,56 & 0,43 & & & \\
\hline $\begin{array}{l}\text { Önállóságra nevelés } \\
\text { célja - Anya }\end{array}$ & & & & & & & 0,87 & 0,82 \\
\hline $\begin{array}{l}\text { Önállóságra nevelés } \\
\text { célja - Apa }\end{array}$ & & & & & & & 0,85 & 0,79 \\
\hline
\end{tabular}


tott konformitást hangsúlyozó nevelés jelent meg. A negyedik faktor pedig, további 9\%-kal magyarázva a varianciát, egy autonómiát támogató családi légkört ír le, ahol kizárólag az apai és anyai önállóságra nevelés kapcsolódott ide.

A fiatal felnôttek esetében szintén egy négyfaktoros megoldás bizonyult a legjobbnak, 63\%-kal magyarázva a varianciát. Az elsố faktor, 22\%-kal magyarázva a varianciát, egy szabályorientált családi légkört ír le, ahol az apai és anyai korlátozó és következetes beállítottság, és a konformitásra nevelés volt a hangsúlyos. A második faktor, 20\%-kal magyarázva a varianciát, egy konfliktusos családi légkört mutat be, ahol az anyai inkonzisztens és támogatást nélkülözô beállítottság, valamint a manipulatív nevelési attitûd volt a domináns. A harmadik faktor, további 22\%-kal magyarázva a varianciát, egy olyan családi légkört ír le, ahol az apai inkonzisztens beállitottság figyelhetô meg elsôsorban, kiegészítve ezt a manipulatív és inkonzisztens nevelési attitúddel. A negyedik dimenzió pedig egy függetlenedést támogató családi légkört ír le, ahol mindkét szülő önállóságot támogató attitúdje megfigyelhetô. A második vizsgálatban (2018) a két csoport összehasonlítása során megfigyelhettük, hogy a serdülốk esetében az apai következetes és inkonzisztens beállítottság egy idôben is megjelent, míg a fiatal felnôttek körében az apai inkonzisztens beállítottság egy külön dimenziót alkotott. Ez az eredmény a nevelési mintázatok részben eltérô észlelését mutatja a két vizsgált korosztályban, melyben tükröződhet a szülôkrôl, és elsôsorban az apáról kialakított kép különbsége is a serdülôkor és fiatal felnôttkor között.

\section{A faktorok ekvivalenciája a két mérési időpontban}

Mindkét mérési idôpontban (2002 és 2018) összehasonlítottuk, hogy a serdülôk és a fiatal felnôttek faktorstruktúrája mennyiben mutat hasonlóságot. A serdülók esetében két faktor hasonlóságot mutatott mind elnevezésében, mind tartalmában a két mérési idôpontban. A faktorok egyezésének vizsgálatára Tucker-féle phi együtthatót számoltunk ki (Lorenzo-Seva és Berge, 2006; Van De Vijver és Leung, 1997). A Tucker együttható akkor mutat egyezést a faktorok között (konstruktum ekvivalencia), hogyha az értéke 0,85 feletti. A serdülook csoportjában két faktor esetében (Konfliktusos családi légkör és Szabályorientált családi légkör) egyezést találtunk (Tucker phi együttható: 0,85, 0,86), két faktor (Önállósodási törekvések támogatása, Apai következetesség) azonban nem mutatott egyezést (Tucker phi: 0,26).

A megegyezó faktorok itemeibôl skálákat képeztünk, és így két skála rajzolódott ki: (1) a konfliktusos, nem támogató, manipulatív légkör és (2) a szabályorientált, konformitást hangsúlyozó és korlátozó szülőii attitûdöket hangsúlyozó családi légkör. Ezek mentén elvégeztük a serdülő csoportok összehasonlítását a két mérési idôpontban. A képzett skálák megbízhatósága megfelelố volt (lásd 5. táblázat).

A két mérési idôpontban összehasonlítva a serdülők percepcióját, a konfliktusos családi légkörben találtunk szignifikáns különbséget. Az eredmény azt mutatta, hogy 2018-ban a serdülók szignifikánsan $\left(\mathrm{F}_{(1,259)}=10,566, \mathrm{p} \leq 0,001\right)$ alacsonyabb mértékú (átlag $=3,18$, szórás $=1,07$ ) konfliktust észleltek, mint a 2002-es mérés során (átlag = 3,56, szórás =1,03). Míg a szabályorientált családi légkör dimenziójában nem mutatkozott szignifikáns különbség $\left(\mathrm{F}_{(1,259)}=2,198, \mathrm{p}=0,24\right)$. 
5. táblázat. A közös skálák reliabilitása és leíró statisztikája

\begin{tabular}{l|c|c|c}
\hline Skálák & Itemek & Átlag (szórás) & Cronbach-alpha \\
\hline $\begin{array}{l}\text { Konfliktusos családi } \\
\text { légkör }\end{array}$ & 9 & $3,03(0,82)$ & 0,81 \\
\hline $\begin{array}{l}\text { Szabályorientált } \\
\text { családi légkör }\end{array}$ & 8 & $3,48(0,85)$ & 0,82 \\
\hline
\end{tabular}

A fiatal felnôttek esetében is megvizsgáltuk a faktorok ekvivalenciáját. A Tucker phi együttható alapján csak egy faktor esetén, a Szabályorientált légkör faktornál találtunk egyezést a két mérési idôpontban (Tucker phi: 0,87), a másik három faktor esetében nem találtunk egyezést (Konfliktusos légkör Tucker phi: 0,15, Önállósodási törekvések támogatása Tucker phi: 0,22, Apai következetesség Tucker phi: 0,21).

A Szabályorientált légkör faktorból skálát képezve (5. állítás, átlag = 3,14, szórás = 1,02, $\alpha=0,79)$ összehasonlítottuk a két mérési idôpontban a fiatal felnôttek percepcióját. Az eredmények szignifikáns különbséget mutattak $\left(\mathrm{F}_{(1,345)}=11,449, \mathrm{p} \leq 0,001\right)$, 2002-ben a fiatal felnôttek szignifikánsan magasabb (átlag = 3,24, szórás = 1,07) szabályorientációt észleltek a szülôi nevelésben, mint 2018-ban (átlag = 2,79, szórás = 0,96).

\section{Életkori különbségek - keresztmetszeti mérések}

1. vizsgálat (2002): Kétszempontos varianciaanalízis (családi struktúra x korcsoport) segítségével megvizsgáltuk a szignifikáns különbségeket a szülôi nevelési dimenziókban. Szignifikáns életkori különbség $\left(\mathrm{F}_{(2,259)}=11,222 ; \mathrm{p} \leq 0,001\right)$ mutatkozott a szabályorientált nevelési légkör dimenziójában. A fiatal felnőttek szignifikánsan szabályorientáltabbnak (átlag $=3,24$, szórás $=1,07$ ) észlelték a családi nevelési légkört, mint a serdülôk (átlag $=2,79$, szórás $=0,96)$. Az anyai következetes beállítottság szintén különbözött életkoronként $\left(\mathrm{F}_{(1,261)}=5,87 ; \mathrm{p} \leq 0,016\right)$. A fiatal felnôttek szignifikánsan következetesebbnek észlelték édesanyjuk nevelési stílusát (átlag = 3,55, szórás =1,04), mint a serdülők (átlag $=3,19$, szórás $=1,06$ ). Emellett a fiatal felnóttek édesanyjuk nevelését konformitást hangsúlyozóbbnak is látták $\left(\mathrm{F}_{(1,257)}=7,48, \mathrm{p} \leq 0,007\right.$; átlag = 3,22, szórás $=0,95$ ), mint a serdülook (átlag = 2,91, szórás =0,92). Az anyai korlátozás tekintetében szintén életkori különbséget azonosíthattunk $\left(\mathrm{F}_{(1,261)}=10,787, \mathrm{p} \leq 0,001\right)$, amely szerint a fiatal felnôttek (átlag $=4,42$, szórás $=1,01$ ) korlátozóbbnak észlelték anyjuk nevelési stílusát, mint a serdülook (átlag = 3,98, szórás = 1,35).

2. vizsgálat (2018): Szignifikáns különbséget találtunk a serdülők és fiatal felnôttek között mindkét szülô konformitásra nevelési stílusában. A fiatal felnôttek mind édesapjuk, mind édesanyjuk nevelését konformitást hangsúlyozóbbnak észlelték, összehasonlítva a serdülókkel. A korlátozó nevelés tekintetében szintén életkori különbség mutatkozott, miszerint a fiatal felnôttek szignifikánsan korlátozóbbnak észlelték mindkét szülő nevelési stílusát. Míg az apai támogató nevelési attitûd esetében a serdülők észleltek nagyobb mértékú apai támogatást a fiatal felnôttekkel szemben (lásd 6. táblázat). 
6. táblázat. Életkori különbségek a nevelési stílusok észlelésében

\begin{tabular}{l|c|c|c}
\hline Nevelési stílus & $\begin{array}{c}\text { Serdülök } \\
(\mathbf{n}=\mathbf{1 3 3}) \\
\text { átlag (szórás) }\end{array}$ & $\begin{array}{c}\text { Fiatal felnóttek } \\
(\mathbf{n}=\mathbf{2 0 4}) \\
\text { átlag (szórás) }\end{array}$ & $\begin{array}{c}\text { Csoportok } \\
\text { osszehasonlítása }\end{array}$ \\
\hline Konformitás nevelési cél - Anya & $3,11(0,95)$ & $3,38(1,08)$ & $\mathrm{F}_{(1,336)}=5,43^{*}$ \\
\hline Konformitás nevelési cél - Apa & $2,94(1,18)$ & $3,23(1,26)$ & $\mathrm{F}_{(1,336)}=6,63^{*}$ \\
\hline Korlátozó nevelési attitúd - Anya & $3,92(1,28)$ & $4,23(1,27)$ & $\mathrm{F}_{(1,336)}=4,64 *$ \\
\hline Korlátozó nevelési attitúd - Apa & $3,87(1,46)$ & $4,44(1,43)$ & $\mathrm{F}_{(1,336)}=12,13^{* *}$ \\
\hline Támogató nevelési attitúd - Apa & $4,53(1,26)$ & $4,00(1,40)$ & $\mathrm{F}_{(1,336)}=12,05^{* *}$ \\
\hline
\end{tabular}

Megjegyzés: $* \mathrm{p}<0,05, * * \mathrm{p}<0,01$

A statisztikai elemzés nem mutatott jelentôs különbséget a két adatbázis között. Mindkét vizsgálat esetén megfigyelhettük, hogy a retrospektív beszámolók hasonló mintázatot mutattak 16 év elteltével is. Csak egy esetben figyelhettünk meg változást, amely azt mutatta, hogy a serdülők nagyobb mértékú apai támogatásról számoltak be, mint a fiatal felnôttek.

\section{Családi struktúra szerinti különbségek}

1. vizsgálat (2002): Szignifikáns különbséget azonosíthattunk $\left(\mathrm{F}_{(1,256)}=11,457, \mathrm{p} \leq 0,001\right)$ a családi struktúra alapján (teljes vagy egyszülős család) a szabályorientált családi légkör megítélésében. Azok a fiatalok, akik teljes családban nevelkedtek, szignifikánsan szabályorientáltabbnak (átlag = 3,21, szórás = 1,06) észlelték a családi légkörüket, mint azok a fiatalok, akik elvált családban nevelkedtek (átlag = 2,77, szórás = 0,99).

2. vizsgálat (2018): Szignifikáns különbséget azonosíthattunk a konfliktusos családi légkör megítélése tekintetében. Az eredmények azt mutatták, hogy azok a fiatalok, akik elvált családban nevelkedtek, szignifikánsan konfliktusosabbnak észlelték a családi környezetüket, mint akik teljes családban nevelkedtek. A családi struktúra alapján szintén különbség mutatkozott az inkonzisztens és manipulatív anyai nevelési attitúdben. Az eredmény azt tükrözte, hogy azok a fiatalok, akik egyszülôs családban nevelkedtek, édesanyjuk nevelési stílusát inkonzisztensebbnek és manipulatívabbnak észlelték, mint azok, akik teljes családban nôttek fel. Az apai nevelést is negatívabbnak látták az elvált szülôk gyermekei: manipulatívabbnak, kevésbé támogatónak és következetesnek ítélték meg (lásd 7. táblázat).

Az egyszülôs családok fiataljainak neveléssel kapcsolatos észlelési különbségeit is megvizsgáltuk életkor szerint, hogy megismerjük az esetleg megjelenô megítélési sajátosságokat, eltéréseket. Az elsố csoportba tartoztak a serdülők $(\mathrm{N}=22)$, a második csoportba pedig a fiatal felnôttek $(\mathrm{N}=43)$. Elemzésünk azt bizonyította, hogy az elvált családban nevelkedô fiatal felnốttek mindkét szüloo nevelési stílusát korlátozóbbnak és édesanyjuk nevelését konformitást hangsúlyozóbbnak észlelte, szemben az elvált családban nevelkedô serdülôkkel (lásd 8. táblázat). 
7. táblázat. A családi struktúra hatása a nevelési stílusok észlelésére

\begin{tabular}{l|c|c|c}
\hline Nevelési stílus & $\begin{array}{c}\text { Egyszülós családok } \\
(\mathbf{n}=\mathbf{6 5}) \\
\text { Atlag (szórás) }\end{array}$ & $\begin{array}{c}\text { Teljes családok } \\
(\mathbf{n}=\mathbf{2 2 7}) \\
\text { Átlag (szórás) }\end{array}$ & $\begin{array}{c}\text { Csoportok } \\
\text { ossszehasonlítása }\end{array}$ \\
\hline Konfliktusos családi légkör & $3,48(0,84)$ & $3,02(0,70)$ & $\mathrm{F}_{(1,298)}=20,78^{* *}$ \\
\hline Inkonzisztens nevelési attitúd - Anya & $2,70(1,58)$ & $2,21(1,27)$ & $\mathrm{F}_{(1,298)}=7,12^{* *}$ \\
\hline Manipulatív nevelési attitûd - Anya & $2,87(1,37)$ & $2,36(1,21)$ & $\mathrm{F}_{(1,298)}=9,01 * *$ \\
\hline Manipulatív nevelési attitûd - Apa & $2,52(1,12)$ & $2,16(0,95)$ & $\mathrm{F}_{(1,298)}=7,09 * *$ \\
\hline Támogató nevelési attitûd - Apa & $3,74(1,56)$ & $4,35(1,33)$ & $\mathrm{F}_{(1,298)}=10,57 * *$ \\
\hline Következetes nevelési attitúd - Apa & $3,13(1,51)$ & $3,56(1,38)$ & $\mathrm{F}_{(1,298)}=10,20^{*}$ \\
\hline
\end{tabular}

Megjegyzés: *p $<0,05, * * \mathrm{p}<0,01$

8. táblázat. Különbségek a nevelési stílusok észlelésében családi struktúra alapján

\begin{tabular}{l|c|c|c}
\hline Szülői nevelés & $\begin{array}{c}\text { Egyszülős csalá- } \\
\text { dok (serdülök) } \\
(\mathbf{n}=\mathbf{2 2}) \\
\text { Átlag (szórás) }\end{array}$ & $\begin{array}{c}\text { Egyszülós családok } \\
\text { (fiatal felnőttek) } \\
(\mathbf{n}=\mathbf{4 3 )} \\
\text { Átlag (szórás) }\end{array}$ & $\begin{array}{c}\text { Csoportok } \\
\text { összehasonlítása }\end{array}$ \\
\hline Konformitásra nevelési cél - Anya & $3,23(1,11)$ & $3,72(1,10)$ & $\mathrm{F}_{(2,335)}=4,62^{* *}$ \\
\hline Korlátozó nevelés - Anya & $4,31(1,13)$ & $4,66(1,10)$ & $\mathrm{F}_{(2,335)}=5,21^{* *}$ \\
\hline Korlátozó nevelés - Apa & $3,95(1,52)$ & $4,89(1,06)$ & $\mathrm{F}_{(2,335)}=5,45^{* *}$ \\
\hline
\end{tabular}

\section{MEGVITATÁS}

Vizsgálatunk újszerûségét az adja, hogy összehasonlítja a fiatal felnôttek és a serdülők gyermeknevelési tapasztalatait. Ezen túl arra is vállalkozott ez a tanulmány, hogy megvizsgálja a társadalmi, gazdasági és politikai változás lehetséges hatását a szüloói nevelésre a fiatalok észlelésén keresztül.

Elsônek azt emelnénk ki, hogy az adatok szerint a két mérési idôpontban a két korosztály jórészt hasonló dimenziókban észleli a szülői nevelést, így a harmadik feltételezésünk részben beigazolódott. A korábbi és késôbbi mérés serdülőinél és fiatal felnốttjeinél egyaránt megjelent a szabályorientált családi klíma faktora, amely tartalmazta a konformitás célját, a korlátozás attitúdjét és a következetes beállítottságot. Szintén hasonló faktor volt a négy csoportban a konfliktusos családi klíma együtt az apai és anyai manipulatív, következetlen beállítottsággal és a nem támogató attitûddel. A fiatal felnôttek két csoportja és a második mérés serdülői hasonlónak észlelték az autonómia nevelési cél faktort a szülôi nevelésben, valamint az apai negatív nevelési faktort és az ehhez kapcsolódó inkonzisztens beállítottságot, a korlátozó és nem támogató attitúdöt. Az elsố mérés serdülőinek faktorai eltérô képet mutattak, náluk ugyanis a szabályorientált és a konfliktusos családi klíma mellett harmadik faktornak az apai és anyai következetes és autonómiát nem engedô nevelési cél jelenik meg. A másik három csoport hasonló faktorszerkezete azt mutatja, hogy a politikai és társadalmi változások ellenére a serdülók és a fiatal felnôttek családi nevelésrôl alkotott retrospektív 
észlelése meglehetôsen hasonló dimenziók mentén szerveződik. Ez két szempontból is lényeges eredmény.

Egyrészt úgy tûnik, hogy a nevelési stílus észlelésének hosszabb távú hasonlósága részben igazolható. Ezt egyrészt a nevelési stílus generációs átadásával magyarázhatjuk, ami a jelen vizsgálatban különbözó szülői kohorszokra nézve értendô, de a nagyobb csoportok szintjén ez mégis a nevelési stílusok hasonlóságát eredményezi. Az elsajátított és a különbözô pszichológiai funkciók által közvetített nevelési szokások és módszerek továbbadása így lehetôvé teszi a nevelési mintázatok hosszabb távon is érvényesülő fennmaradását. A nevelési stílus stabilitásához a fejlődési fülke homeosztatikus múködése is hozzájárulhat. Super és Harkness (1986) elmélete szerint a fülke egyensúlyra törekvô múködése a változó körülmények esetén is biztosítja a relatíve stabil családi nevelést, vagyis a tudatosan vagy nem szándékosan átvett nevelési stílusjegyek csak kevéssé módosulnak a társadalmi hatások kapcsán, ezzel magyarázható tehát az, hogy a nevelés fontosabb dimenziói inkább stabilnak tûnnek a különbözô fiatal kohorszok észlelése alapján. Ugyanakkor arra is gondolhatunk, hogy a társadalomban tartósan jelen lévô familizmus (Dupcsik és Tóth, 2008), ennek ideológiai és társadalmi állapot aspektusa is olyan közvéleményt és attitúdöket erôsít meg, amelyek kedveznek a nevelési módszerek igazolásának és fennmaradásának, és ez hozzájárul e módszerek fiatalok általi percepciójához.

Az észlelt nevelés több dimenziójának hasonlósága amiatt is figyelmet érdemel, mert Russell és munkatársai (2016) felhívják a figyelmet arra, hogy a szülói nevelést vizsgáló kérdôívekben jelentkezô különbségek gyakran abból adódnak, hogy a kitöltô személyek máshogy konstruálják meg a tapasztalataikat. Mivel a mi vizsgálatunkban a két mérési idôpontban és a két életkori csoportban is viszonylag hasonló másodrendú faktorszerkezetet találtunk, ezért felvetôdött az a kérdés, hogy statisztikailag igazolható-e a faktorok és így az észlelés foobb dimenzióinak a tényleges hasonlósága a két időpontot tekintve.

Az elemzés azt mutatta, hogy a serdülők a két időpontban csak a Konfliktusos és a Szabályorientált nevelési légkört észlelték teljesen hasonló dimenziók mentén. Az Önállósodási törekvések támogatásában és az Apai következetesség faktorban eltéréseket tapasztaltunk. A fiatal felnôttek esetében pedig csak a Szabályorientáció dimenzióban mutathattunk ki egyezést a konstruktumekvivalencia-vizsgálatok alapján a két mérési időpontban, a többi faktorban kisebb-nagyobb eltérések jelentek meg például az anyai és az apai nevelést érintô dimenziókban.

A hasonló szervezôdésú nevelési dimenziókkal végzett számítások azt igazolták, hogy a serdülôk a két idôpontban eltérôen ítélték meg a szülői nevelést. A 2018-ban vizsgált serdülők kevésbé látták konfliktusosnak gyerekkoruk szülői nevelôi légkörét, mint a 2002-ben válaszolók, jóllehet a hatfokú skála felezópontján megjelenô 2002-es érték is azt tükrözi, hogy csak igen csekély mértékú volt a megtapasztalt családi összeütközés. Ez az eredmény azt mutatja, hogy a korábbiakhoz képest változott a serdülôk észlelése 2018-ban, kevesebb nézeteltérést, illetve nagyobb harmóniát látnak a szülókkel való kapcsolatban. Ez összhangban van azzal az eredménnyel, amely szerint a szülốk nevelési stílusa megváltozott, kevésbé élezik ki a konfliktusokat, és inkább megegyezésre törekszenek a serdülő́k nevelése során (Branje, Van Doorn, Van der Valk és Meeus, 2009). A fiatal felnôttek csoportjában is hasonló jellegú változást ta- 
pasztaltunk, de más nevelési dimenzióban, ami az életkorra jellemzô sajátos észlelési fókuszt is jelzi. A 2002-es mérés szerint a húszévesek csoportja, ha kismértékben is, de valamivel erôsebb szabályorientációt, következetességet és konformitást észlelt gyerekkorukkal kapcsolatban, mint a 2018-ban vizsgált csoport. A különbségek átlagát is figyelembe véve az eredmény azt igazolja, hogy a késôbbi idôszakban nevelô családokban a fiatal felnôttek, szemben a másik felnôtt csoporttal, még kevesebb kötöttséggel, még gyengébb szabálykövetéssel és következetességgel jellemezték a szülői nevelést, mint a 2002-es vizsgálat felnôttjei. Bár ezek a hasonló szerkezetú dimenziókban mért különbségek nem nagyok, mégis úgy tûnik, hogy a késôbbi periódusban nevelkedó két korosztály kisebb mértékú szigorúságot és nagyobb harmóniát tapasztalhatott meg a családjában, mint a korábbi nemzedékek.

Az elsố hipotézisben azt fogalmaztuk meg, hogy a 2002-es mérésnél a fiatal felnôttek korlátozóbbnak, célorientáltabbnak és kevésbé önállóságra nevelônek látják a szülối nevelést, szemben a serdülookkel, hiszen az engedelmesség és szülői tekintély, vagyis az autoriter nevelési stílus volt jellemzô a társadalmi változás elôtti családi és iskolai nevelési kontextusban (Robila, 2004). Az eredmények azt mutatták, hogy az elsố mérésnél a fiatal felnôttek, összehasonlítva a serdülőkkel, szabályorientáltabbnak látták a családi klímát, az anyát pedig következetesebbnek, korlátozóbbnak és konformitásra nevelônek. A második mérésnél is hasonló különbség mutatkozott a két életkori csoport között: a fiatal felnôttek mindkét szülōt korlátozóbbnak és inkább konformitást hangsúlyozónak látták, sốt ez a különbség az elvált családok fiataljainak megítélésére is jellemzô volt. Ez alapján azt mondhatjuk, hogy a korlátozás és konformitás különbségei a szülôi nevelés észlelésében inkább életkori különbséggel magyarázhatók, a társadalmi változás hatását tehát nem sikerült megbízható módon igazolni a 2002-es eredményekre vonatkozóan. Ugyanakkor az elsô mérésnél a serdülők kevésbé látták szabályorientáltnak és következetesnek a szülôi nevelést, mint az idôsebb korosztály, és ez a különbség nem jelent meg a második vizsgálatban. Ez az eredmény arra utalhat, hogy a politikai változás után szocializálódott serdülôk kevésbé szabálykövetônek észlelték a szülői nevelést, ami összhangban van azzal a szakirodalmi adattal, hogy a változások során szabadabb társadalmi légkör alakult ki, és a szülooi tekintély mellett megjelent a gyerekek nagyobb önállósága (Robila, 2004).

A második feltételezésünkkel éppen ellentétes eredményt kaptunk, ugyanis a 2018-as mérés során a felnôtt korosztály nem autonómiát, hanem konformitást észlelt a gyerekkori nevelési céllal kapcsolatban, és inkább korlátozónak látta az apa és az anya nevelési attitûdjét, szemben a serdülôkkel. Mivel a két korcsoport között az életkori eltérés csak öt év, így kevésbé valószínú, hogy a szülői nevelés célja és módszere ilyen rövid idői különbséggel jelentôsen megváltozott volna, tehát kevéssé hihetô, hogy a gyerekkori nevelés valódi különbségeinek pontos észleléséról lenne szó. Mivel az elsố vizsgálatban is hasonló jellegú különbséget tapasztaltunk, így inkább az életkor mentén jelentkezô eltéréssel magyarázhatjuk a fiatal felnôttek konformitást és korlátozást hangsúlyozó észlelését. Ennek a megértéséhez közelebb visz, ha figyelembe vesszük a neveléssel kapcsolatos megítélés torzításait. A szülôi nevelés retrospektív észlelését több tényezô is módosíthatja (Gerlsma és mtsai, 1990). A nem szándékos pontatlanság és a felejtés mellett a visszatekintô észlelést befolyásolja a válaszadó jelenlegi társas kapcsolatainak minôsége (Dalton és mtsai, 2006), a depressziós tünetek 
erôssége és a hangulat módosítása is (Gillham és mtsai, 2007). Ez alapján több magyarázat is lehetséges. Elképzelhetô, hogy a fiatal felnôttek szülookkel való kapcsolata nem teljesen pozitív például a szülôk és fiatalok értékkülönbségei miatt, így ezt a mostani kapcsolati problémát vetítik vissza a gyerekkori nevelés jellemzésére. De az is felvethetô, hogy az új értékrendet és életstílust képviselô fiatalokkal szemben a szülők valóban korlátozó, irányító módon lépnek fel, és ezt a jelenleg észlelhetô nevelési stílust vetítik vissza a gyerekkori élményekre. Ehhez hasonló az az összefüggés, amely szerint a fiatalok szélesebb explorációja (identitással kapcsolatos keresési, információgyújtési folyamata) kiváltotta a szülók korlátozó magatartását (Luyckx és mtsai, 2007), a szüló és gyerek kapcsolat reciprok, kétirányú jellege tehát ebben az életkorban is igazolható. Feltételezhetố továbbá az is, hogy a fiatalok hangulata, érzelmi állapota nem teljesen kiegyensúlyozott a részleges önállóság, a tanulmányok okozta problémák és kettô között lenni (már nem serdülô, még nem felnôtt) érzése (Arnett és mtsai, 2014) miatt, így a hangulatnak megfelelô negatívabb értékelés jelenik meg a válaszadásban. A fiatal felnôttekre jellemzô, hogy kevesebb a kötelessége és a társas szerepe a felnôttekhez képest, ugyanakkor a szülôk csak fokozatosan tudják elfogadni a gyermekeik erôsödô függetlenségi és önállósági törekvéseit (Arnett és mtsai, 2014), így tartós feszültség alakulhat ki a szülők és a fiatalok között. További magyarázati lehetôséget kínál, ha figyelembe vesszük, hogy a fiatal felnôttek olyan egyetemi környezetben tanulnak, ahol nagyobb a döntési szabadságuk és az önállóságuk gyakorlási lehetôsége, és ehhez a nagyobb szabadsághoz képest észlelik korlátozóbbnak és konformistának a gyerekkori szülôi nevelést. További vizsgálat szükséges ahhoz, hogy feltárjuk, melyik tényezô vagy tényezók okozzák az észlelés sajátos mintázatát a fiatal felnoottek csoportjában.

Az elvált és intakt családok különbségei a várt dimenziók mentén alakultak, így a negyedik hipotézisünk is igazolást nyert. Az elvált családokban a fiatalok mindkét idôpontban konfliktusosabbnak látták a gyermekkori családi klímát, a második mérésben pedig ez kiegészült azzal, hogy az apát és az anyát manipulatívnak, kevésbé következetesnek ítélték meg, illetve az apát kevésbé látták támasznyújtónak. Ezek az eredmények összhangban vannak Amato (2000), Lansford (2009), valamint Hetherington és Stanley-Hagan (2002) eredményeivel, amelyek szerint válás esetén több a konfliktus, kevesebb a szülối támasz, kevésbé következetes a szülôi fegyelmezés és irányítás. Az elvált családok fiataljainál azt is ellenôriztük, hogy vajon van-e különbség a két életkori csoport között. Az eredmények csak a már ismert életkori különbséget tükrözték, vagyis a fiatal felnôttek konformistább célokat tulajdonítottak az anyának, és mindkét szülốt korlátozóbbnak látták, mint a serdülôk. A fiatalokra és a serdülókre jellemzô észlelési különbség tehát az elvált családban élôknél is megtalálható, másfajta észlelési vagy értékelési dimenzió viszont nem jelent meg a korosztályok összehasonlításakor.

A vizsgálat számos korlátja óvatosságra int az eredmények általánosítása tekintetében. A minta elemszáma miatt csak kevéssé generalizálhatók a kapott eredmények. Az értelmezés során fontos szempont továbbá, hogy a fiatal felnôtt korosztály egyetemi hallgatókból állt, így lehetséges, hogy az ô sajátos családi helyzetük miatt látják konformitásra nevelônek és korlátozónak a gyerekkori nevelést, és más rétegbe tartozó fiatal esetén ettôl eltérô eredményt kaptunk volna. A sajátos különbségek nemcsak a minta szerkezetébôl adódhattak, hanem a kérdőív dimenzióiból is. Ez alapján felvethetó, hogy az alkalmazott szocializációs kérdôív itemjei és dimenziói nem voltak igazán ér- 
zékenyek a társadalmi és gazdasági változások hatásának mérésére. Ugyanakkor a két mérési idôpontban kapott hasonló életkori különbségekre az is magyarázatként szolgálhat, hogy a vizsgált rétegekben a családok hatásosan tudták kompenzálni a negatív társadalmi hatásokat, így a hátrányosabb helyzetú vagy szegényebb körülmények között élő rétegek nevelési nehézségei nem jelenhettek meg a fiatalok észlelése szintjén.

Az eredmények további kérdéseket vetnek fel. Érdemes lenne megvizsgálni például, hogy mennyire általános jelenség más kultúrákban és más országokban a fiatal felnốttek korlátozást és konformitást hangsúlyozó észlelése a gyerekkori neveléssel kapcsolatban. Fontos kérdés továbbá az is, hogy milyen tényezók állnak a fiatal felnôttek retrospektív észlelésének hátterében. Az életkori különbséget jelzó eredmények alapján az is felvethetô, hogy érdemes lenne longitudinális vizsgálattal feltárni a nevelésre vonatkozó élmények változását, formálódását, illetve az erre ható tényezôket és azok kapcsolatát.

\section{IRODALOM}

Amato, P. R. (2000). The consequences of divorce for adults and children. Journal of Marriage and the Family, 62(4), 1269-1287.

Arnett,J.J. (2000). Emerging adulthood. The theory of development from the late teens through the twenties. American Psychologist, 55(5), 469-480. DOI: 10.1037//0003-066X.55.5.469

Arnett, J. J., Žukauskienė, R., \& Sagimura, K. (2014). The new life stage of emerging adulthood at ages 18-29 years: implications for mental health. Adolescent mental health 3. Lancet Psychiatry, 1, 569-576.

Barber, B. L., \& Eccles, J. S. (1992). Long-term influence of divorce and single parenting on adolescent family- and work-related values, behaviors, and aspirations. Psychological Bulletin, 111(1), 108-126.

Belsky, J., Conger, R., \& Capaldi, D. M. (2009). The intergenerational transmission of parenting: introduction to the special issue. Developmental Psychology, 45(5), 1201-1204.

Branje, S. J. T, Van Doorn, M., Van der Valk, I., \& Meeus, W. (2009). Parent-adolescent conflicts, conflict resolution types, and adolescent adjustment. Journal of Applied Developmental Psychology, 30(2), 195-204. https://doi.org/10.1016/j.appdev.2008.12.004

Csepeli, Gy., \& Prazsák, G. (2009). Újszegénység. A digitális egyenlôtlenség kulturális hatásai. In Antalóczy, T., Füstös, L., \& Hankiss, E. (szerk.): Vészjelzések a kultúráról. Budapest: MTA Politikai Tudományok Intézete. http://www.prazsak.hu/publikaciok/csepeli_prazsak_ujszegenyseg_2009.pdf (Letöltve: 2011. február 10.)

Dalbert, C., \& Goch, J. (1997). Gerechtigkeitserleben und familiale Socialisation. In H. P. Langfeldt (Ed), Informationen, Programm, Abstracts (p. 60.). London: Verlag Empirische Pädagogik.

Dalton, W. T., Frick-Horbury, D., \& Kitzmann, K. M. (2006). Young adults' retrospective reports of parenting by mothers and fathers: Associations with current relationship quality. The Journal of General Psychology, 133(1), 5-18. doi.org/10.3200/GENP.133.1.5-18

Dimler, L. M., Natsuaki, M. N., Hastings, P. D., Zahn-Waxler, C., \& Klimes-Dougan, B. (2017). Parenting effects are in the eye of the beholder: parent-adolescent differences in perceptions affects adolescent problem behaviors. Journal Youth and Adolescence, 46(5), 1076-1088. DOI 10.1007/s10964-016-0612-1

Dunovsky, J. (1996). Family in society in transition. In Nakou, S., \& Pautelakis, S. (Ed), The child in the world of tomorrow. The next generation. Pergamon: Guilford.

Dupcsik, Cs., \& Tóth, O. (2008). Feminizmus helyett familizmus. Demográfia, 51(4), 307-328. 
East, L., Jackson, D., \& O'Brien, L., (2006). Father absence and adolescent development: a review of the literature. Journal of Child Health Care, 10(4), 283-295. DOI: 10.1177/1367493506067869

Gerlsma, C., Emmelkamp, P,M.G. \& Arrindell, W.A. (1990). Anxiety, depression, and perception of early parenting: a meta-analysis. Clinical Psychology Review. 10(3). 251-277. DOI:10.1016/0272-7358(90)90062-F

Gillham, J. E., Putter, P., \& Kash, V. M. (2007). The effects of sad mood on reports of parents' caregiving behavior. Journal of Psychopathology and Behavioral Assessment, 29(2), 125-133. DOI $10.1007 / \mathrm{s} 10862-006-9031-\mathrm{z}$

Giczi, J., \& Sik, E. (2009). Bizalom, társadalmi tốke, intézményi kötôdés. In Tóth, I. Gy. (szerk.), TÁRKI Európai társadalmi jelentés 2009 (pp. 65-84.). Budapest: Tárki. www.tarki.hu/hu/ research/gazdkult/gazdkult_gici_sik.pdf (Letöltve: 2010. április 18.)

Guajardo, N. R., Snyder, G., \& Petersen, R. (2009). Relationships among parenting practice, parental stress, child behaviour, and children's social-cognitive development. Infant and Child Development, 18(1), 37-60. DOI: 10.1002/icd.578

Hale, W. W., III, Engels, R., \& Meeus, W. (2006). Adolescent's perceptions of parenting behaviours and its relationship to adolescent Generalized Anxiety Disorder symptoms. Journal of Adolescence, 29(3), 407-417.

Hetherington, E. M., \& Stanley-Hagan, M. (2002). Parenting in divorced and remarried families. In M. H. Bornstein (Ed), Handbook of parenting. Vol. 3. Being and becoming a parent (pp. 287-315.). Second edition. Mahwah, NJ: LEA.

Jámbori, Sz. (2007). Hogyan tervezik a serdülók a jövôjüket? Szeged: SZEK JGYF Kiadó.

Ketskeméty, L., \& Izsó, L. (1996). Az SPSS for Windows programrendszer alapjai. Felhasználói útmutató és oktatási segédlet. Budapest: SPSS Partner Bt.

Kitamura, T., Shikai, N., Uji, M., Hiramura, H., Tanaka, N., \& Shono, M. (2009) Intergenerational transmission of parenting style and personality: direct influence or mediation? Journal of Child and Family Studies, 18, 541-556. DOI 10.1007/s10826-009-9256-z

Kumar, A., Sharma, M., \& Hooda, D. (2012). Perceived parenting styles as a predictor of hope among adolescents. Journal of the Indian Academy of Applied Psychology, 38(1), 174-178.

Lansford, J.E. (2009). Parental divorce and children's adjustment. Perspectives on Psychological Science. 4(2), 140-149. DOI: 10.1111/j.1745-6924.2009.01114.x

LeMoyne, T., \& Buchanan, T. (2011). Does „hovering” matter? Helicopter parenting and its effect on well-being. Sociological Spectrum, 31(4), 399-418. doi:10.1080/02732173.2011.574038

Lorenzo-Seva, U., \& Berge, J. M. F. (2006). Tucker's Congruence Coefficient as a Meaningful Index of Factor Similarity. Methodology, 2(2), 57-64. DOI 10.1027/1614-1881.2.2.57

Luyckx, K., Soenens, B., Vansteenkiste, M., Groossens, L., \& Berzonsky, M. D. (2007). Parental psychological control and dimension of identity formation in emerging adulthood. Journal of Family Psychology, 21(3), 546-550.

Nelson, L. J., Padilla-Walker, L. M., Christensen, K. J., Evans, C. A., \& Carroll, J. S. (2011). Parenting in emerging adulthood: An examination of parenting clusters and correlates. Journal of Youth and Adolescence, 40(6), 730-743. DOI 10.1007/s10964-010-9584-8

Nelson, L. J., Padilla-Walker, L. M., \& Nielson, M. G. (2015). Is hovering smothering or loving? Parental warmth as a moderator of relations between helicopter parenting and emerging adults' indices of adjustment. Emerging Adulthood, 3, 282-285. DOI: 10.1177/ 2167696815576458

Padilla-Walker, L. M., Nelson, L. J., Fu, X., \& McNamara Barry, C. (2018). Bidirectional relations between parenting and prosocial behavior for Asian and European-American emerging adults. Journal of Adult Development, 25(2), 107-120. DOI 10.1007/s10804-017-9272-y

Patterson, G. R. (1982). Coercive family process. Eugene, OR: Castalia. 
Pongrácz T.-né (2002). A család és a munka szerepe a nôk életében. In Pongrácz T.-né, \& Spéder Z. (szerk.): Népesség - értékek - vélemények. KSH Népességtudományi Kutatóintézetének kutatási jelentései 73. 123-138.

Pongrácz T.-né, \& S. Molnár, E. (2011). A nemi szerepmegosztásról, a családi élet és a munka összhangjáról alkotott vélemények változása 2000-2009 között. In Pongrácz T.-né (szerk.): KSH Népességtudományi Kutatóintézetének kutatási jelentései 91. 95-112.

Ponnet, K., Mortelmans, D., Wouters, E., Van Leeuwen, K., Bastaits, K., \& Pasteels, I. (2013). Parenting stress and marital relationship as determinants of mothers' and fathers' parenting. Personal Relationship, 20(2), 259-276. DOI: 10.1111/j.1475-6811.2012.01404.x

Robila, M. (2004). Families in Eastern Europe: Context, trends and variations. In M. Robila (ed), Families in Eastern Europe. Contemporary Perspectives in Family Research, Vol. 5 (1-14). Emerald Group Publishing Limited. doi:10.1016/S1530-3535(04)05001-0

Russell, J. D., Graham, R. A., Neill, E. L., \& Weems, C. F. (2016). Agreement in youth-parent perception of parenting behaviors: a case for testing measurement invariance in reporter discrepancy research. Journal of Youth and Adolescence, 45(10), 2094-2107. DOI 10.1007/ s10964-016-0495-1

Shifflet-Chila, E., Harold, R. D., Fitton, V. A., \& Ahmedani, B. K. (2016). Adolescent and family development: autonomy and identity in the digital age. Children and Youth Services Review, 70, 364-368.

S. Molnár, E. (2011). Párkapcsolat létesítését/megszüntetését érintô magatartási normák változásának megfigyelése. In Pongrácz T.-né (szerk.): KSH Népességtudományi Kutatóintézetének kutatási jelentései 91. 37-68.

Soenens, B., Elliot, A. J., Goossens, L., Vansteenkiste, M., Luyten, P., \& Duriez, B. (2005). The intergenerational transmission of perfectionism: psychological control as an intervening variable. Journal of Family Psychology, 19(3), 358-366.

Steinberg, L., \& Silk, J. S. (2002). Parenting adolescents. In M. H. Bornstein (Ed), Handbook of parenting. Vol. 1. Children and parenting (pp. 103-133.). Second edition. Mahwah, NJ: LEA.

Super, C. M., \& Harkness, S. (1986). The developmental niche: A conceptualization at the interface of child and culture. International Journal of the Behavioral Development, 9(4), 545-569.

Tóth, I. Gy. (2009). Bizalomhiány, normazavarok, igazságtalanságérzet és paternalizmus a magyar társadalom értékszerkezetében. A gazdasági növekedés társadalmi/kulturális feltételei. A TÁRKI kutatási terve. Budapest: TÁRKI.

Tóth, O. (1997/2006). Családformák és együttélési minták a mai magyar társadalomban. In Lévai, K., \& Tóth, I. Gy. (szerk.), Szerepváltozások. Jelentés a nók és férfiak helyzetéról (pp. 73-85.). Budapest: TÁRKI, Munkaügyi Minisztérium Egyenlő Esélyek Titkársága,. Elektronikus verzió készült 2006-ban.

Tóth, O., \& Dupcsik, Cs. (2007). Családok és formák - változások az utóbbi ötven évben Magyarországon. Demográfia, 50(4), 430-437.

Van De Vijver, F. J. R., \& Leung, K. (1997). Methods and Data Analysis for Cross-cultural. Research. London: Sage.

Van IJzendoorn, M. H. (1992). Intergenerational transmission of parenting: a review of studies on nonclinical populations. Developmental Review, 12, 76-99.

Vazsonyi, A. T., Hibbert, J. R., \& Snider, J. B. (2003). Exotic enterprise no more? Adolescent reports of family and parenting processes from youth in four countries. Journal of Research on Adolescence, 13(2), 129-160.

Wolfradt, U., Hempel, S., \& Miles, J. N. V. (2003). Perceived parenting styles, depersonalisation, anxiety and coping behaviour in adolescents. Personality and Individual Differences, 34, $521-532$. 
A cikk a Creative Commons Attribution 4.0 International License (https://creativecommons. org/licenses/by/4.0) feltételei szerint publikált Open Access közlemény, melynek szellemében a cikk bármilyen médiumban szabadon felhasználható, megosztható és újraközölhetô, feltéve, hogy az eredeti szerzô és a közlés helye, illetve a CC License linkje és az esetlegesen végrehajtott módosítások feltüntetésre kerülnek. (SID_1)

\title{
YOUNG PEOPLE' PERCEIVED PARENTING STYLES: SOCIAL AND SOCIETAL EFFECTS
}

\author{
JÁMBORI, SZILVIA- KÖRÖSSY, JUDIT
}

Background and aims: The first part of the present study sought to answer whether the retrospective perceptions of education of young adults raised in the socialist system and adolescents mostly socialized in the new social, political system reflect social and family transformations beginning with regime change. Based partially on these results, the aim of the second part of the study was to demonstrate how family structure and social relationships of the two age groups affect the differences in perception.

Method: 271 young adults took part (123 men and 148 women) in the first study (2002), while in the second study (2018) there were 337 subjects (149 men and 188 women). On both occasions, subjects had to fill in the Family Socialization Questionnaire (Dalbert and Goch, 1997) that measures parenting practices retrospectively.

Results: According to the second-order factor analyses on both occasions both age groups perceive parenting styles similarly. Young adults perceive parenting styles as more restrictive and show a higher level of conformity compared to adolescents in both studies. Comparing the similar construction of parenting factors results proved that adolescents perceived fewer conflict and young adults saw weaker rule-orientation in the family in 2018 than those in the first study.

Consequences: The similarities of the perceptions of parenting between the two age groups could be explained with the stability of the parenting styles and with the homeostatic mechanism of the developmental niche (Super and Harkness, 1986). The later generations living in greater freedom in social life (Robila, 2004) due to the longer consequences of social and political changes perceived fewer conflicts and restrictions in their family life. Young adults' memories of conformity and restriction could be explained as a perception bias resulting from their special social and family situation.

Keywords: perception of parenting, age group differences, political-societal changes, retrospective study 